\title{
Communication Behavior of Tasikmalaya Embroidery Craftsmen in Maintaining Sustainability of Local Wisdom-Based Enterprises
}

\author{
Santi Susanti \\ Faculty of Communication Science \\ Universitas Padjadjaran \\ Sumedang, Indonesia \\ santi.susanti@unpad.ac.id
}

\author{
Fitri Perdana \\ Faculty of Communication Science \\ Universitas Padjadjaran \\ Sumedang, Indonesia \\ fitri.perdana@unpad.ac.id
}

\author{
Rachmaniar \\ Faculty of Communication Science \\ Universitas Padjadjaran \\ Sumedang, Indonesia \\ rachmaniar01@gmail.com
}

\begin{abstract}
Tasikmalaya is known as a center of the various traditional craft industry. One of them is embroidery. Embroidery skills are local knowledge passed down from generation to generation. Continuity of handicraft business can be interpreted as economic improvement and maintenance of local community wisdom. The endurance of the business in the midst of competition with more modern products is the main reason for doing this research. This research aims to reveal the communication behavior of Tasikmalaya embroidery craftsmen in maintaining the continuity of business in the midst of global competition. This research uses a qualitative method with phenomenology approach. Research data collected through direct observation and in-depth interview with embroidery craftsmen in Tasikmalaya City. Documentations provided to complete the research data obtained from the informants. The results showed, entrepreneurial communication behavior in maintaining business continuity done internally and externally. Internal communication runs in families and with employees in business and production management using interpersonal communication and group communication. External communications are aimed at consumers to market products using interpersonal communication and mediated communication.
\end{abstract}

Keywords—craft industry; local wisdom; business sustainability

\section{INTRODUCTION}

Embroidery is one of Tasikmalaya typical handicrafts that already known domestically and abroad. The craft center is located in Kawalu sub-district. Most of the production is still done in small and medium enterprises (SMEs/UKM), with the number of employees between five to twelve people. The production method is done in two ways by using automatic embroidery machines and ordinary sewing machines. The production process with automatic embroidery machine is done to pursue the number of garments produced, mass production. Manual embroidery, done by skilled hands using an ordinary sewing machine. The quantity produced of manual embroidery usually not much. The priority of manual embroidery handicraft is the aesthetic value and the quality of the material. The selling price is different. Manually embroidered clothes are more expensive than clothing embroidered with machines.

Embroidery knowledge and skills are largely gained through a long-standing transmission process from parents to their children, or from families, neighbors and/or communities through informal education in the form of direct practice. This is called local knowledge (indigenous knowledge), which is part of local wisdom. Local wisdom is a source of knowledge that is organized dynamically, developed and continued by a particular population that is integrated with their understanding of nature and the local culture. Local wisdom, also contained local cultural wisdom, a local knowledge that has been so united with the belief system, norms, and culture and expressed in the traditions and myths adhered to in the long term. Local wisdom or traditional wisdom is the knowledge, belief, understanding or insight and ethical customs that guide human behavior in ecological life. So local wisdom is a pattern of human behavior associated with other humans, nature and the unseen.[1].

Embroidery skills can improve the lives of the craftsmen as well as lift the economic development of the people. In practice, many parties are involved in the process of running this embroidery business. In order to maintain business continuity, communication between the relevant parties, such 
as workers, consumers and government institution is required. This study aims to reveal the communication behavior of Tasikmalaya embroidery craftsmen in preserving the continuity of their business based on local wisdom.

Communication behavior is any activity that aims to seek and obtain information from various sources and to disseminate information to any party that requires[2]. Communication behavior is an individual inherent action in the social process in which each individual launches an interactive behavior with each other. Individuals always produce messages using language as a means of communication. The act of communication itself takes place in the context of interpersonal, group, organization and mass communication.[3]

\section{RESEARCH METHOD}

This research was conducted by using qualitative method with phenomenology approach. According to Creswell [4], phenomenological research is a strategy of inquiry in which the researcher identifies the essence of human experiences about a phenomenon as described by participants. Understanding the lived experiences marks phenomenology as a philosophy as well as method, and the procedure involves studying a small number of subjects through extensive and prolonged engagement to develop patterns and relationships of meaning.

Methods of data collection is done through in-depth interviews to informants and field observations to see the production process of embroidery craft. Informants are taken using purposive sampling with snowball technique. This research was conducted in Tasikmalaya City, with informant owner of Ariesta Bordir in Mangkubumi Sub-district and owner of Raisa Bordir, in Cipedes Sub-district, Tasikmalaya City. The informant is a manual embroidery craftsman who has been in business for more than five years and still maintains their business amid the many machinery embroidery entrepreneurs.

\section{RESULT \& DISCUSSION}

\section{A. Brief History of Embroidery Crafts In Tasikmalaya}

Historically [1], Tasikmalaya embroidery industry first grew and developed in 1925 in Tanjung Village, Kawalu Subdistrict, Tasikmalaya City. One of the pioneers was a woman named $\mathrm{Hj}$. Umayah binti $\mathrm{H}$. Musa, who in the previous year worked for an American company, Singer. After mastering the field of embroidery while working in Singer, she went out and returned to Tanjung Village and opened a small business by receiving embroidery orders from both Tasikmalaya and from outside the region. In addition to opening a business, $\mathrm{Hj}$. Umayah also provides her knowledge by training her family, neighbors and close relatives in the embroidery business, because it is considered to have a promising prospect. After $\mathrm{Hj}$. Umayah passed away, this business continued by her family, among others, H. Rosad, H. Sarbeni, H. Sarhasih and H. Zarkasie. From there, the embroidery business is growing fast not only in the Tanjung Village, Kawalu Sub-district, but also spread to other areas, such as Sukaraja, Tanjungjaya, Singaparna, Sukarame, Cibalong, Cikatomas and other areas.
In 1955 the craftsmen produce only to meet the needs of local market around Tasikmalaya and Ciamis, but after a conflict between the population with DI/ TII that forced Tasikmalaya youth to become the army of Islam, many young Tasikmalaya resigned to Jakarta. To survive, Tasikmalaya youths sell crochet skills to Chinese businessmen in Jakarta. The figures are H. Rosyad, H. Jarkasih and H. Sarhasih.

After DI / TII surrendered to the Indonesian National Army in 1966, Tasikmalaya became safe, the youths in Jakarta returned to Tasikmalaya with embroidery orders from Chinese businessmen in Jakarta. Since then the production of embroidery strived massively by the community with laborintensive models. The product is accommodated by $\mathrm{CV}$ Kernasio which is the people's economic institution formed by $\mathrm{H}$. Rosyad and his friends

Initially, the famous embroidery craft in Tasikmalaya was manually embroidered, using a regular sewing machine that was moved by feet, which called mesin kejek (the engine of the steering wheel) by the embroidery artisans. Sewing machine model is estimated to start entering Indonesia around 1920, then known by the juki machine after a visit from Japan and provide assistance in the form of sewing machines that have Juki brand. Now known as the juki machine. Along with technological developments, juki machines are marginalized by new, more economical and efficient engines capable of producing much more with the same quality of embroidery machines using computer technology (Computer Embroidery). However, the manual embroidery craftsmen survive. They continue to produce with consideration to preserve the historical heritage and as a form of responsibility for employees who have worked for more than a dozen years.

Communication behavior can be interpreted as a shared tool to express ideas and feelings that we feel to the other person, so that others know it correctly [5]. Communicators can react or convey their thoughts well to others so that communication behavior puts pressure on stimuli made by the source and the reaction given by the recipient[6]. Similarly, the communication that occurs between entrepreneurs embroidery with the parties involved in the process of production and product marketing. Using language and nonverbal behavior, embroidery entrepreneurs communicate to the parties around them with the goal of maintaining the continuity of its production and marketing of embroidery products.

\section{B. Communication Behavior of Craftsmen in Family Environment: Maintaining Consistency of Production and Product Quality}

The embroidery industry in Tasikmalaya is mostly done in home scale. Management is entrusted to the family. Beyond the family, there are employees who work on embroidery for stock or order. In the family environment, craftsmen play a role as the responsible of the continuity of running embroidery business. Maintaining consistency of production and product quality is the main work done, in addition to promoting and expanding product marketing. Efforts are made to maintain consistency of production and product quality, among others, with each craftsman trying to produce new models on a regular basis and maintaining the copyrighted design of the 
resulting model by not handing over the production process to another party, but rather self-produced. Artisans protect the results of the design, so as not to fall into the hands of others so that the model is not the market and the quality generated is maintained.

\section{Communication Behavior to Employees: Egalitarian and Kinship}

Every manual embroidery entrepreneur usually has a permanent employee who does embroidery at the home of the entrepreneur. The presence of skilled embroidery employees has an important role in the continuity of manual embroidery business, because skilled workers like them at this point are difficult to obtain. Regeneration process does not run smoothly, because there are employees who do not want their children to be embroidered, or vice versa, children do not want to learn embroidery and choose to undergo other work than embroidery.

Employees are usually outside the family environment. However, the relation of communication between them is quite familiar, especially for those who have worked for a long time. The principle of egalitarian and kinship is applied in communicating with employees. In addition, communication is woven not only with employees only, also with their families. Tuti of Raisa Bordir stated as follows:

"Treating the employees must be with the heart. If using the heart, whatever our disappointment with his work, I am sure there will something positive for me. So I've never been directly cut employee salary. I told them to be more carefull next time.”

Communication with employees is mostly done through interpersonal communication delivered directly to employees. The goal is for employees to understand immediately the instructions delivered.

\section{Communication Behavior to Customers: Exhibitions and Online Media}

Buyers are an important element in the business of manual embroidery, because the price is not cheap. Loyalty to the product is needed to maintain the continuity of the relationship between artisans as producers with buyers as consumers. Generally, consumers of embroidery manuals are established individuals, including officials, employers and art workers, as well as boutiques. For that, it takes a media that can keep the relationship between craftsmen and consumers. Online exhibitions and media are the right choice to keep in touch with consumers, as well as to expand the market.

Unlike embroidery machines that prioritize quantity, manual embroidery puts the work of art worth and quality of materials as the main benchmark of the product it produces. With a limited amount and prices are not cheap, making craftsmen introduce and market their products directly through the exhibition and online media.

In each exhibition, craftsmen can interact directly with potential buyers about the embroidery products manually produced. Potential buyers can see and feel directly the quality of the products on display. Trading transactions can be done, if consumers are interested to buy products on display.

Another way is through online media. Various media are used by embroidery craftsmen manually in marketing their products, including Whatsapp (WA), Facebook, Instagram and website. The use of online media is intended in addition to marketing the product, as well as for branding / promotion of manual embroidery products and Kota Tasikmalaya, because not everyone can come to Tasikmalaya to buy direct embroidery products produced manually.

The use of online media is able to help the marketing of manual embroidery products to a wider market share. In sales, the composition of products sold through coming directly with online media is almost balanced. However, there are times when sales through online media raises doubts from prospective buyers will the quality of goods offered. To overcome this, usually on the artisans show photo documentation of activities related to manual embroidery offered, so that potential buyers believe with the quality of the goods produced.

To maintain good relationships with customers, manual embroidery craftsmen provide repair or compensation services for products purchased by consumers within certain limits of reasonableness, such as uncontrolled defective products. In addition, to keep the relationship with customers, craftsmen take time to greet customers just to ask for news, while offering new products. It turns out to be useful and effective in maintaining good relationships with customers. Approximately $60 \%$ of customers remain maintained communications ties with craftsmen.

\section{E. Communication Behavior to Government Institution: Promotion and Training}

Government Institution have a role in advancing the embroidery industry in Tasikmalaya City. Government institution are concerned to maintain the image of Tasikmalaya as a craft center in West Java. Based on informant's explanation, the role of Government institution at this time is to help the promotion of embroidery products by providing booths in exhibitions held inside and outside the country. In addition, Government institution also provide training in order to improve the skills of the craftsmen in managing their business. Communication behavior common in interaction with Government institution is transactional. The government offers assistance for promotion and training, while craftsmen could choose to accept or reject the offers by the government. In turn, artisans can ask for government assistance to do overseas promotion.

Government institution in question include the Department of Cooperatives UMKM, Industry and Trade (KUKM Perindag) Tasikmalaya City and BUMN. In contrast to regional agencies, BUMN offer more to selected craftsmen to be fostered by providing financial support for business development, excluding promotions and training.

\section{F. Local Wisdom in Tasikmalaya Embroidery Craft}


Tasikmalaya embroidery crafts are known for a long time. Its presence has become the hallmark of Tasikmalaya City. Skills possessed by predecessor craftsmen are then passed on to the next generation. Inheritance is generally given through direct practice, both in the production process and in marketing, so that the pattern applied in the past is formed and become a typical management pattern that only takes place in Tasikmalaya.

Local wisdom in the management of Tasikmalaya embroidery is applied among others in the embroidery model creations that are mostly taken from nature, in the form of animals or flowers. In addition, consistency in applying religious moral principles believed by Tasikmalaya residents, known as the City of Santri is characteristic in the management of Tasikmalaya embroidery craft. The belief that everyone is given a fortune by God is firmly entrenched in the person of Tasikmalaya embroidery entrepreneur so that the competition between craft entrepreneurs can be limited by the concept of fate and fortune different from one another given by God. They assume, everyone has a way of life and fortune.

The value of wisdom applied, among others, honest, keep promises and respect others. Value is instilled in families and communities, especially to the younger generation. Craftsmen always strive to satisfy the customer and try not to disappoint the customer, the buyer is the king who must be respected.[1]

\section{CONCLUSION}

Embroidery craft is one of the various handicrafts that characterize Tasikmalaya. The center is located in District Kawalu, Tasikmalaya City. Handicrafts are estimated to grow in 1920 has developed into a creative economy that can boost the economy of Tasikmalaya residents. Its production is growing, not only the embroidery on the bed sheets, pillowcases, tablecloths and handkerchiefs, but evolved into various types of clothing for women, children and men.

Embroidery crafts originally done through ordinary sewing machines, now developed with an automatic embroidery machine, which can produce more clothes. However, the craftsmen who still use ordinary sewing machines are not gone. There are still craftsmen who survive to produce manual embroidery with a reason to maintain the distinctive embroidery Tasikmalaya at the beginning of its existence, and maintain the quality of embroidery based on the value of art contained in it.

The process of producing and marketing embroidery products cannot be done alone. There are parties involved. The sustainability of the production and marketing process is determined by the communication behavior carried out by the business owner to the parties related to his business, such as employees, consumers and Government institution. The communication behavior applied to each party varies by importance. Communication behavior in the family environment of craftsmen is done to maintain consistency of production and product quality. Behavior of communication to employees is applied in an egalitarian manner and applying the principle of kinship. Behavior of communication to customers is intended to maintain loyalty and expand marketing through online exhibitions and media. Communication behavior to Government institution is aimed at promoting and improving skills in managing craft businesses through seminars and training

In relation to local wisdom, Tasikmalaya embroidery craftsmen retain the identity of Tasikmalaya as a craftsman's center in West Java. Principles of local wisdom applied, among others, keeping the promise and appreciate other people instilled in the family and society. Craftsmen always try not to disappoint customers and establish relationships with customers in relation to maintaining ukhuwah and extend customer loyalty. In managing its business, the craftsman prioritizes the family and maintains good relationships with employees in order to establish a mutually beneficial business.

\section{ACKNOWLEDGMENT}

I would like to thank those who have helped me with the research. Mrs. Risma Hareni and Kang Iman Ramdani from Ariesta Bordir, Mrs. Tuti from Raisa Bordir, Mr. Arif from Dinas UMKM Indag Kota Tasikmalaya for the time spent for this research.

\section{REFERENCES}

[1] Y. Darusman, "Kearifan Lokal Kerajinan Bordir Tasikmalaya Sebagai Ekonomi Kreatif Terbuka untuk Modern [Local Wisdom of Tasikmalaya's Embroidery Craft as Open Creative Economy for Modern],” J. Nonform. Educ., vol. 2, no. 2, pp. 1-13, 2016.

[2] Suranto, Komunikasi Interpersonal [Interpersonal Communication]. Yogyakarta: Graha Ilmu, 2011.

[3] A. Bajari, "Konstruksi Makna dan Perilaku Komunikasi Pada Anak Jalanan di Cirebon [Construstion of Communication Meanings and Behavior on Street Children in Cirebon],” Universitas Padjadjaran, 2009.

[4] J. W. Creswell, Research Design: Qualitative, Quantitative and Mixed Methods Approaches. California: SAGE Publications Inc., 2009.

[5] J. Rakhmat, Psikologi Komunikasi [Communication Psychology]. Bandung: PT. Remaja Rosdakarya, 2011.

[6] H. Cangara, Pengantar Ilmu Komunikasi [Communication Science Introduction]. Jakarta: Rajawali Press, 2002. 